Bu makaleye atıfta bulunmak için/To cite this article:

MISIRLI, G. ERGÜN, Z. GÜNERİ, B. (2021). The Street in the Focus of Concepts of Security/Insecurity:

Representation of News About the Street on Internet News. Atatürk Üniversitesi Sosyal Bilimler Enstitüsü Dergisi, 25 (Özel Sayı), 365-384.

\title{
The Street in the Focus of Concepts of Security/Insecurity: Representation of News About the Street on Internet News
}

\author{
Gülsemin MISIRLI $\left.{ }^{*}\right)$ \\ Zuhal ERGÜN ${ }^{(* *)}$

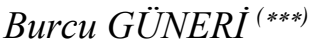

\begin{abstract}
The forms of representation created by media are fundamental in affecting people and societies. Media builds a reality in the viewer's mind with its contents by using language and words. In this sense, this study aims to question how the street is represented in the media through internet news sites. Thus, what the street means conceptually is mentioned and also discussed street's concepts, security/ insecurity. According to the rating measurement company Alexa's data, the most followed news sites in Turkey are sözcü.com.tr, ensonhaber.com.tr, hurriyet.com.tr. The news about the street in the article was analyzed in the context of critical discourse analysis. The online archives were scanned with the keyword "street"; The news that emphasizes the idea that the street is dangerous and has a higher power to affect individuals was evaluated within the study's scope. As a result, it was seen in the news published on internet news sites that the street is positioned as unsafe, dangerous, even as a place of transition from one place to another, and as a place that should be abandoned. Some solutions were made in line with the results of the examinations.
\end{abstract}

Keywords: Internet news sites, street, representation, security/insecurity.

\section{Güven/Güvensizlik Kavramları Odağında Sokak: İnternet Haber Sitelerinde Sokak Konulu Haberlerin Temsili}

Öz: Medyanın oluşturduğu temsil biçimleri insanları ve toplumlart etkilemede son derece önemlidir. Zira medya ürettiği içeriklerle okurun/izleyicinin zihninde bir gerçeklik inşa etmekte; bunu kullandiğı dil ve sözcükler aracılığıyla gerçekleştirmektedir. Bu doğrultuda çalışmanın amacı, sorunlu bir temsil alanı olduğunu düşündüğümüz sokağın medyada nasıl temsil edildiğini internet haber siteleri üzerinden sorgulamaktır. Bu nedenle çalışmada sokağın kavramsal olarak neyi ifade ettiğine değinilmiş; ayrıca sokak, güven/güvensizlik kavramları bağlamında tartışılmıştır. Çalışmanın araştırma bölümünde ise, reyting ölçüm şirketi Alexa'nın verilerine göre, Türkiye'de en çok takip

*) 100/2000 YÖK Doktora Burslu Öğrencisi, Atatürk Üniversitesi Sosyal Bilimler Enstitüsü Gazetecilik Anabilim Dalı (e-posta:gulseminmisirli60@gmail.com) (D) ORCID ID. https://orcid.org/0000-00018103-8462

${ }^{* * *}$ 100/2000 YÖK Doktora Burslu Öğrencisi, Atatürk Üniversitesi Sosyal Bilimler Enstitüsü, Temel İletişim Bilimler Anabilim Dalı (e-posta:zuhalergun86@gmail.com) (D) ORCID ID. https://orcid.org/ 0000-0003-3982-0682

${ }^{* * *)}$ Öğretim Görevlisi, Atatürk Üniversitesi Yabanc1 Diller Yüksekokulu (e-posta: burcuguneri48@gmail.com) (D) ORCID ID. https://orcid.org/0000-0002-0898-7853

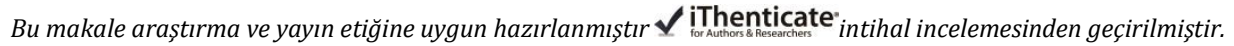


edilen haber sitelerinden sozcü.com.tr, ensonhaber.com.tr ve hurriyet.com.tr'de yer alan sokak konulu haberler eleştirel söylem analizi bağlamında incelenmiştir. Söz konusu sitelerin çevrimiçi arşivleri 'sokak' anahtar sözcüğü ile taranmış; sokağın tehlikeli olduğu düşüncesine en çok vurgu yapan ve bireyleri etkileme gücü daha yüksek olduğu düşünülen haberler çalışma kapsamında değerlendirilmiştir. Sonuç olarak, internet haber sitelerinde yer alan haberlerde sokağın güvensiz, bir yerden bir yere geçiş mekânı olarak bile tehlikeli ve hızla terk edilmesi gereken bir yer olarak konumlandırıldı̆̆ı görülmüştür. Yapılan incelemelerden çıkan sonuçlar doğrultusunda bazı çözüm önerilerinde bulunulmuştur.

Anahtar Kelimeler: Internet haber siteleri, sokak, temsil, güven/güvensizlik.

Makale Geliş Tarihi: 03.04.2021

Makale Kabul Tarihi: 27.11.2021

DOI: 10.53487/ataunisosbil.908833

\section{Introduction}

Media is an essential tool that gives individuals an idea about what is happening in the outside world. Individuals interpret and make sense of the external world through the reality created by the media. The media creates a perception about the environment we live in and the world through its programs, TV series, and news. Therefore, the media does this subconsciously without making individuals noticeable. In internet journalism, which is a significant news provider for individuals today, news can reach the reader faster thanks to the fast news flow, and internet news sites can provide more data in terms of quantity than printed newspapers. When considered in this context, internet news sites' potential to mobilize / influence readers are higher. However, as in other media outlets, internet news sites contain much content that does not directly reflect the truth but represents the truth. One of these forms of representation is news about the street. Streets, which are defined as places where vehicles and pedestrians flow daily, are a virtual social platform in bringing people of all ages and groups together, merging and integrating them. The streets are also where organization, solidarity, and acting in unity, and even as Lefebvre said, (Lefebvre, 2013: 23) the revolution begins. However, the street has become one of many risk areas that permeate every aspect of an individual's life and create insecurity and anxiety. Therefore, considering the street's social function, the issue of representation in the media is crucial.

\section{Street Concept and Street as an Unsafe Place Perception}

In the Turkish dictionary of the Turkish Language Association (TDK), the street is defined as a place, province, district, and road in residential areas with houses on both sides, narrower or shorter than the street. (TDK, 2011: 180) However, it is not enough to describe the street with just this definition. Because the street should be handled with the meaning and functions it assumes, so the definition should be made in this direction. The street is an essential social platform as it brings people of all ages and groups together. The power of the street comes from here. Streets; can melt people of different opinions and beliefs in the same 
pot. Therefore, the street has a cohesive and integrative feature. Besides, the streets provide organization, solidarity, and acting together. Streets are also places where culture and social memory are kept alive, as Çakı mentioned. The names of national heroes, influential artists, scientists, politicians, or significant events are given to the streets/avenues are among the leading indicators of this. However, the streets are places where social reactions, demands, and will are expressed (Çakı, 2017: 32).

The street is different from the church, mosque, and museum. It has no walls, or rather borders. It does not have a law; it welcomes people from all walks of life. The man of modern society, who is forced to withdraw, gets rid of the monotony of his life for a short time if he walks into the street corners. The street offers us what is worth seeing and hearing without waiting for a response. It is possible to fill the dark bases of life with light and explore the street's shady areas. The street invites us to a realistic experience of the world. It leads us to rethink our knowledge, truths, and beliefs with suspicion. There is hardly any more ideal place than the street to detach yourself, go out, and have something out of the ordinary (Ülgen, 2018: 6).

Streets are the primary spaces of the public space that form a defined urban unity. It is a texture organizer that connects the whole city beyond the local and determines the local texture. Avenues and streets are not only areas reserved for pedestrian and traffic circulation. These areas appeal to two different worlds of society; it is public property that everyone wants to appear in and private property where each person finds a private life. The street, which is a part of the city, has always existed to direct public life. This area, which covers social life foundations, forms the most legible and most visible state of the public sphere. Streets mediate between the permanence of urban life in the long term and the temporality of urban life in the short term. Besides, these areas, which have a homogeneous structure that create visual continuity, lead to heterogeneous formations and diversity (Gökgür, 2008: 8081).

Bayraktar and his colleagues described the street as a new world to be discovered. According to them, the street provides exciting games and acquaintances with its uncertainty and limitlessness stepped after the house's warmth. First of all, as neighbors, neighborhoods, gardens and friends, grocery stores, bagel shops, butchers are experienced, the street's borders grow, and uncertainties decrease. The feeling of insecurity caused by not being able to make sense of things gives way to self-confidence over time (Bayraktar vd., 1994: 43).

According to Le Corbusier, the street includes functions that are ignored. These are informative, symbolic, and ludic functions. We play there, we learn there. Street means disorder. All urban life elements, which are fixed and redundant elsewhere, become free to fill the streets and flow from the streets to the centers, where they meet each other as these elements retreat to their shelters. This disorder is living. In a sense, this disorder means a higher order (Lefebvre, 2013: 22- 23). As Sennett emphasizes, what gives the street its value 
is the power of discovering something that the eye does not expect to see. The street is mostly a symbol of warning from unexpected experiences (Sennett, 1999: 176).

In his book Urban Revolution, Henri Lefebvre, one of the vital street studies' names, did not neglect to treat the "power of the street" and take the street in political terms. According to Lefebvre, the street is more than just a place for movement and circulation. A street is also a meeting place. It is impossible to meet other designated encounters (cafes, cinemas, parks) without the street. Also, such public spaces give life to the street. Lefebvre also listed the events that will occur after the disappearance of the street: "The disappearance of all life, the reduction of the city to a dormitory, the aberrant functionalization of existence..." (Lefebvre, 2013: 22-24). According to Lefebvre, a street is also a place that embraces unacceptable political views, incurable heartbreaks, and almost everything the society disgusted. However, it is also the site of revolutionary action. Revolutions take place in the streets. This situation shows us that the disorder of the street creates a different order. A street is a privileged place where the word is spoken, and the word becomes written, even a place where the word can become wild and escape from institutions and be written on the walls (Lefebvre, 2013: 23).

Until the ancient Middle Ages, main streets were mentioned; today's street concept has started to be mentioned from this period onwards. Today, it is still possible to see the traces of medieval streets in city centers. During this period, the streets are narrow and curved, lacking tract, sewage, and hygiene. Except for the main street, other streets in the cities do not have stone pavement. There are traders, children playing games, jesters telling funny stories, acrobats, and musicians in the streets. Streets have undergone the first substantial changes since the $16^{\text {th }}$ century. During the Renaissance, the streets were made more programmed (Gökgür, 2008: 84- 85). 17th century, clothing codes were used to bring order to the mixture of foreigners on the Street in Western Europe. At that time, the clothing code, that is, the costumes showing the person's position, enabled the people to be determined clearly (Sennett, 1999: 98- 99, 101). All these show that a street is an important place for individuals, so various ways protect the street's safety. In the $19^{\text {th }}$ century, with the introduction of motor vehicles that developed with the industrial revolution, the street changed in size, and narrow streets turned into wide streets (Gökgür, 2008: 84-85). In the past, neighborhood and community ties were closely related to street life, and people even knew the names of people living on the streets. It is accepted that these ties have started to loosen and lost their former importance with modernization, globalization, technological developments, and individualization. In the past, it is known that individuals living on the same street knew each other better, trusted each other more, and with cliché rhetoric, did not even need to lock the doors of their homes (The Young Foundation, 2010: 5).

Jane Jacob's studies have shown that the street (often the street where people pass) is the only possible security tool against criminal violence (theft, rape, assault) in the USA. Wherever the street disappears, crime is organized, and the crime rate increases. On the street and through this space, a group (the city itself) emerges, manifests itself, owns spaces, creates 
The Street in the Focus of Concepts of Security/Insecurity: Representation of News About the Street on Internet News

a time-space that it owns. Such ownership shows that use and use value can dominate exchange and exchange value (Lefebvre, 2013: 23).

However, the street has long been denigrated as the root of urban malice and a place where perverse tendencies are nurtured, expressed, and conveyed (Browning \& Jackson, 2013: 1010). This uncanny appearance of the street is an undeniable fact of modern societies that negatively affect human life and creates insecurity and anxiety in the individual regarding its results. The lack or scarcity of any of these three components, such as security, certainty, and safety, is primarily reduced self-confidence, loss of confidence in one's abilities, and others' intentions; It has such results (Bauman, 2000: 26). This situation also increases incompetence, anxiety, and prudence; error searching and finding; creates expected consequences such as scapegoating and aggression. As stated above, today, the streets are mentioned with security problems; With these problems, the streets do not allow people to develop their sense of spatial belonging, although there are exceptions (Çak1, 2017: 32). Besides, the increase in vehicles and the crime rate causes the street to be a place to escape quickly. This healthy distrust surrounding the street appears as a problematic area of representation because the street is represented as a crime scene in today's media.

\section{Aim and Methodology}

After meeting people's physical needs, their most important expectation is the need for safety (Ömeroğlu, 2012: 332). A person who thinks that there is a trust problem in the society in which she/he lives and is afraid of crime can move away from social life, and this can reduce the quality of life of a person, remain incomplete in terms of self-realization and cause him to become an unhappy person (Kula \& Çakar, 2015: 198). All this reveals how important the perception of security and, accordingly, a safe space perception is for individuals and society. In this respect, the street's representation, which is a public space, in the media is significant. However, when the relevant literature is scanned, it is seen that there is a severe deficiency in this subject and that sufficient studies have not been done. In this sense, the master's thesis "From the Victimized Other Perspective to the News Language's Otherization Project on a Critical Approach," ${ }^{1}$ conducted by Yeliz Koç in 2016, is essential. In this study, Koç examined the street contrast reflected in the news language with the model of Van Dijk's critical discourse analysis with News samples from newspapers and some internet news sites. As a result of the study, it was found that the other who was excluded from the society in the news was victimized by the events he/she suffered on the street, and news texts also othered the street in this way. This study is vital because it discusses the street in the context of the concept of trust/distrust/uncanny/negativity, systematically scans the news published on the three most followed internet news sites for three months and is a more up-to-date analysis of the field in question. The study investigates how the street is presented in the media as a

${ }^{1}$ Koç, Y .: From the Victimized Other Perspective to the News Language's Otherization Process on a Critical Approach [Master Thesis]. İstanbul: İstanbul University Social Sciences Institute, 2016. 
venue through the news on internet news sites. Internet news sites can also have a higher potential to mobilize/influence the reader, as they can quickly transfer the news and provide more data in terms of quantity in the news than printed newspapers. The study's basic assumption is that in Street news on internet news sites, the street is encoded within the framework of unsafe/uncanny space. Based on this assumption, the research seeks answers to the following questions:

- How is the street represented in the news on internet news sites?

- Is it encoded as an unsafe/uncanny place in street News texts?

The critical discourse analysis approach was adopted in the research. Discourse analysis, mostly used in media texts, emerged in the 1960s as an interdisciplinary study field. Discourse analysis is the study of language. Nevertheless, this review is not simple. It involves examining the meaning that lies beyond the semantic and syntactic boundaries of expressions (Çelik \& Ekşi, 2008: 105).

According to many discourse analysts, language means discourse. Discourse does not represent reality. However, structuring and transforming create social reality. Thus, the world is made sense by language (Taylan, 2011: 68). Studies that analyze linguistic structures that develop with an interdisciplinary approach in discourse analysis using the linguistic method are characterized as critical discourse analysis. The prominent representatives of this field are Teun Adrian van Dijk, Norman Fairclough, and Ruth Wodak" (Özer, 2015: 198). Critical discourse analysis tries to understand how language - a social tool-functions in social interactions in society, Power, Power Distribution, institutions, and the stages of formation and sharing of knowledge" (Gür, 2013: 192). In critical discourse analysis, the goal is to achieve understanding and interpret through this reached meaning. The interpretation is to reveal all kinds of information, thoughts, or messages intended to be given in the discourse (Doyuran, 2018: 321).

The universe of this study consists of news sites that broadcast on the internet in Turkey. The sample, according to the rating measurement company Alexa's data since they are the most clicked news sites in Turkey, is determined to be from ensonhaber.com.tr, hurriyet.com.tr and sozcü.com.tr (alexa.com/topsites, 2020). The news analyzed in the study - taking into account the abundance of street news in the online media - was limited to three months covering the dates January 1 - March 31, 2020. The online archives of the selected internet news sites were scanned with the keyword "street," and 203 news about the street were identified. One hundred two of these news ensonhaber.com.tr in; 60 hurriyet.com.tr 41 in sozcu.com.tr the news that was evaluated in the study was selected from among the news samples that we believe provide the most appropriate text and images for the review. In this direction, a total of Nine news stories were examined in terms of title, content, and image, with three news from each internet news site determined as a sample. 
The Street in the Focus of Concepts of Security/Insecurity: Representation of News About the Street on Internet News

\section{Findings}

In this part of the study, ensonhaber.com.tr, hurriyet.com.tr, and sozcu.com.tr analysis of street news from internet news sites using the critical discourse analysis method is given in detail.

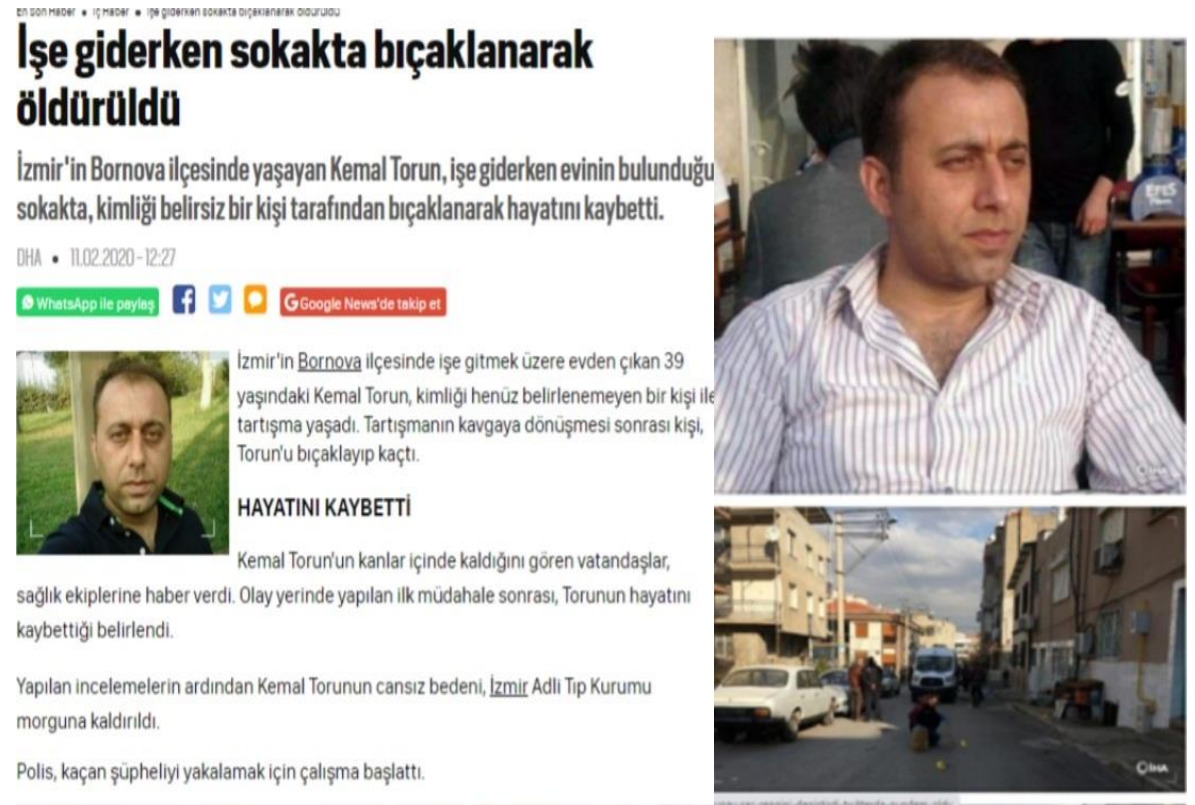

Picture 1: He was stabbed to death in the street on his way to work on the news website ensonhaber.com.tr (2020)

Source: screenshot, ensonhaber.com.tr, 2020

This report, taken from the news site (ensonhaber.com.tr,2020) is about the murder of a person named Kemal Torun by an unidentified person on his way to work in the Bornova district of Izmir. It is seen that the title of the news is constructed with passive language, and the word street is emphasized. In other words, it is emphasized that the person who lost his life was killed on the street rather than by whom he was killed. Again, in the news spotlight, the word street is repeated; the street is presented as the primary address where the murder took place. The street is shown here as the dangerous life outside, and the idea that people have no control over this place is instilled. 2 different photographs were used in the article. 


\section{Gülsemin MISIRLI \\ 372 Zuhal ERGÜN \\ Burcu GÜNERI}

A T A SOBED

202125 (Özel Sayı): 365-384

The first of these is the person who was attacked before he lost his life. The other is the photograph of the crime scene, that is, the place where the person lost his life. This situation aims to establish the opposition of old and new in the reader's mind. The perception that "this person who uses the street to go to work does not live anymore" is dramatically coded through photographs. It can be said that the newsreader is designed in a way that causes anxiety and fear to people who use the street regularly every day and go to work. As Lefebvre emphasizes, passing through the street, which is a communication place, is both compulsory and under pressure (2013: 24) Therefore, here the street is coded as a compulsory transition place to go to work on the one hand and a place where death can be encountered at any time.

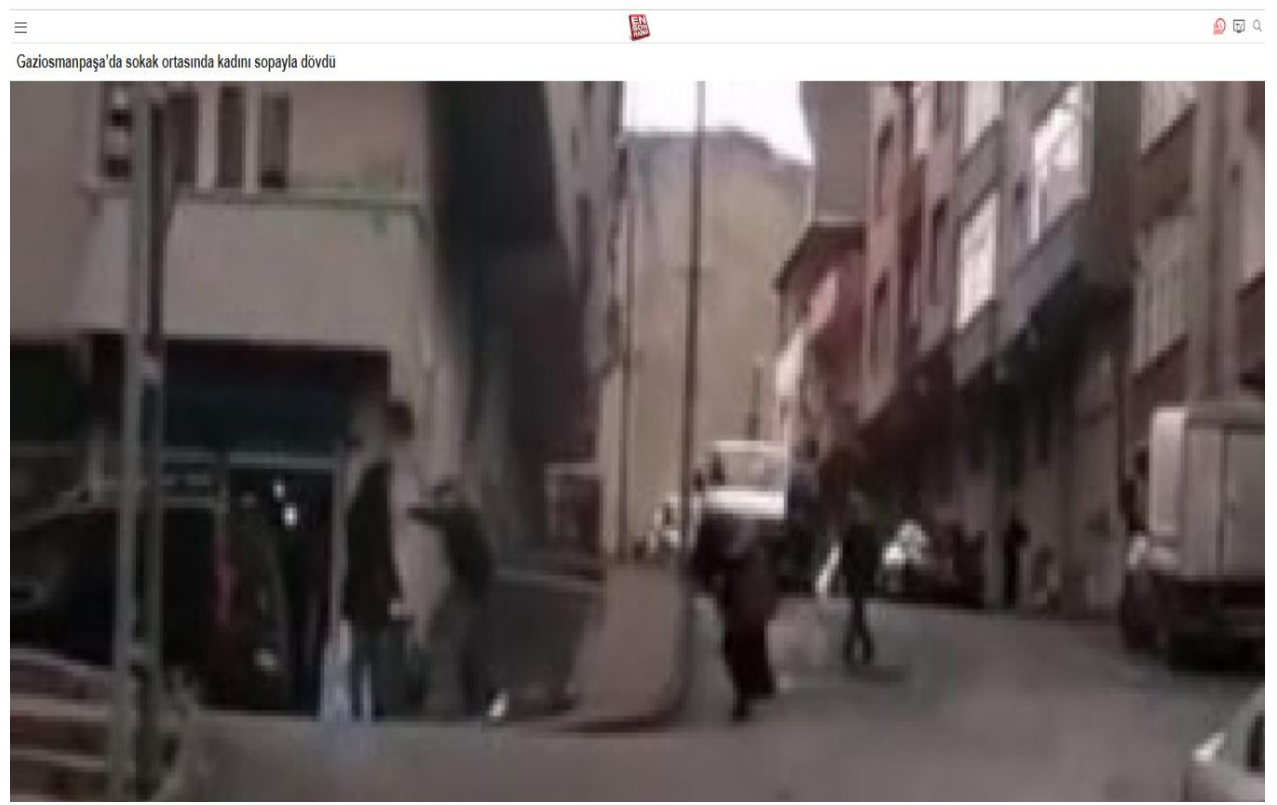

Picture 2: He beat a woman with a stick in the middle of the Street in Gaziosmanpaşa on the news website ensonhaber.com.tr (2020)

Source: screenshot, ensonhaber.com.tr, 2020

The news in Visual 2 (ensohaber.com.tr, 2020) is about a woman being battered by someone allegedly addicted in Gaziosmanpaşa. The word street was repeated in the headline of the news and the spot and text. "He beat the woman to death with a stick in his hand," "he dragged the woman on the floor in the middle of the street" in the news text, such as the woman's violence in the street was repeatedly emphasized. The report did not provide information other than that the person who attacked the woman was addicted and used 
The Street in the Focus of Concepts of Security/Insecurity: Representation of News About the Street on Internet News

violence against the woman. This creates in the reader's mind the idea that all women who go out on the street can be violent at any moment and that the streets are more dangerous for women. As Aktaş stated, some urban spaces are divided into feminine or masculine spaces in the human mind. Most women stay away from urban spaces where they feel anxiety and fear at the thought of threatening their safety, or these spaces are ostracizing women (2007: 141). Also, as Cangöz stated, the street refers to contamination for women (2018: 29). In the way this news is delivered, the situation in question is also felt. The street has the appearance of an exclusionary place.

Clicking on the news first used the news headline, followed by a large photo showing the moment the woman was abused. Even this alone shows that the news is created with an antistreet attitude. A citizen recorded the incident. The Internet news site also used this video in its news content. The violence of the incident was presented to the reader in all its nudity. In the images, it is noticeable that a small number of people are on the street, but they do not help the woman. Thus, the perception that the street is more dangerous when it comes to women has been created.

\section{Adana'da bir kişi evini ateşe verdi}

\section{Adana'da dini nikahlı eşini sokak ortasında döven adam, polisleri görünce evini ateşe vererek kendini içeri kilitledi.}

ІінА • 30.01.2020-04:51

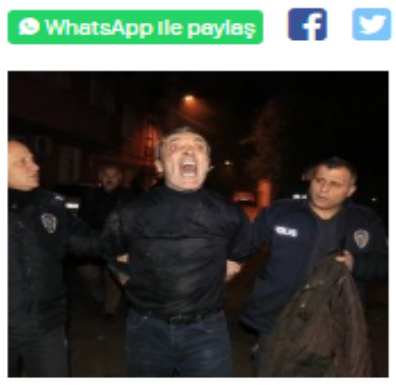

Adana'nın Seyhan ilçesine bağlı Sümer Mahallesi'nde, Ali Y. (51) dini nikahlı eşi O.K (53) ile tartışmaya başladı.

\section{SOKAK ORTASINDA DÖVDÜ}

Kısa sürede büyüyen tartışma kavgaya dönüştü. Ali Y., dini nikahlı eşi O.G.'yi sokak ortasında dövmeye başladı.

Komşuları, durumu polis ekiplerine bildirdi.

KENDINI KILITLEYIP EVINI ATEŞE VERDi

Polisin eve geldiğini gören Ali Y., evi ateşe vererek kendini içeri kilitledi. Bir polis memuru evin kapısını kırarak, yanan evin içerisindeki kadın ve adamı dışarı çıkarttı. Olay yerine gelen itfaiye ekipleri, yangını kısa sürede söndürdü. Ali Y. ise gözaltına alınarak polis merkezine götürüldü.

Picture 3: A person set his house on fire in Adana on the news website ensonhaber.com.tr (2020)

Source: screenshot, ensonhaber.com.tr, 2020 


\section{MISIRLI \\ Burcu GÜNERI}

A T A SOBED

202125 (Özel Sayı): 365-384

In another article titled a person set his house on fire in Adana, (ensonhaber.com.tr, 2020) the word street was not used in the news title. However, it has been repeated many times in the news spot, text, and subtitle. The article is about the discussion of a citizen named Ali Y. with his religiously married wife. The article emphasizes that the woman was beaten "on the street" by the man. In the text, it is stated that a domestic issue was carried to the street. The street is again negated with the expressions "in the middle of the street" and "beat in the middle of the street" repeatedly in the news text. An outdoor photograph was used in the report. In the photograph, where the attacker is in the foreground, the danger is coded with body language and facial expression. In the image where the police hold their arms tightly and the perception that they can escape at any time is created, it is also referred that the dangerous person on the street is a man. In this news, the insecurity or danger of the street is reinforced by the photo.

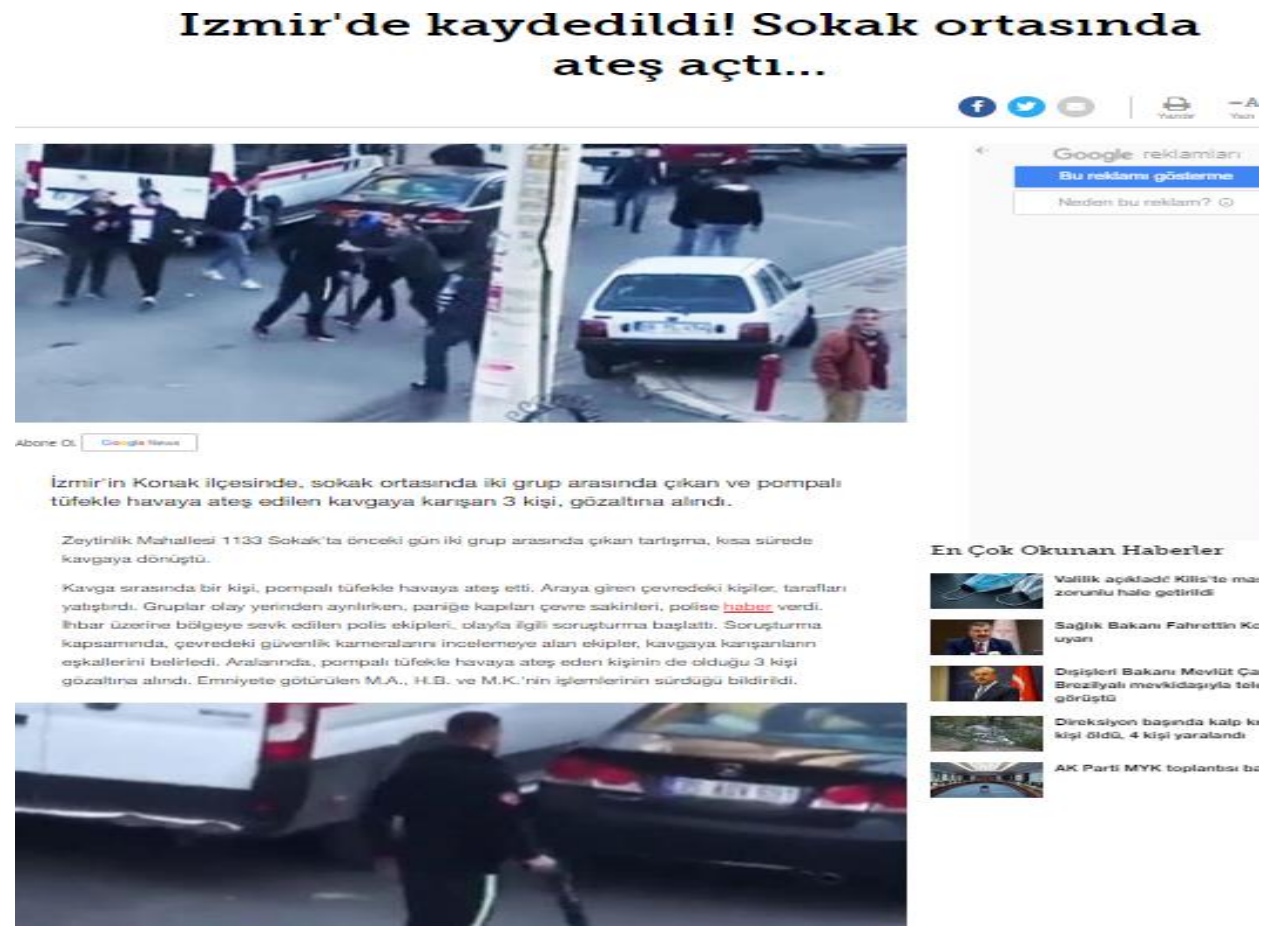

Picture 4: Recorded in İzmir! Fire the gun in the middle of the street on the news website hurriyet.com.tr (2020)

Source: screenshot, hurriyet.com.tr, 2020 
The Street in the Focus of Concepts of Security/Insecurity: Representation of News About the Street on Internet News

"Recorded in Izmir! The news titled "Fire the Gun in the Middle of the Street", (hurriyet.com.tr, 2020) is a fight between the two groups in the Konak district of Izmir. It is seen that the word street is repeated over and over again in the title, spot, and content of the news. In the news, words such as shotgun, fight, opened fire, used in conjunction with the street, cause the street to be coded as a place of violence, fight and fear. The news stated that the people on the street were anxious with the expression "residents of the panicked neighborhood". Thus, the danger of being on the street at that time was emphasized. In the report, which uses two separate photographs, the first photo shows the fight's moment. In the second photo, there is an image of a person carrying a shotgun. The images that make you feel the chaos of the crime scene at first glance prove the danger of the street. In that case, it can be said that photographs support the uncanny of the street.

\section{Tuzla'da bankadan çıkan kişiye sokak ortasında kapkaç}
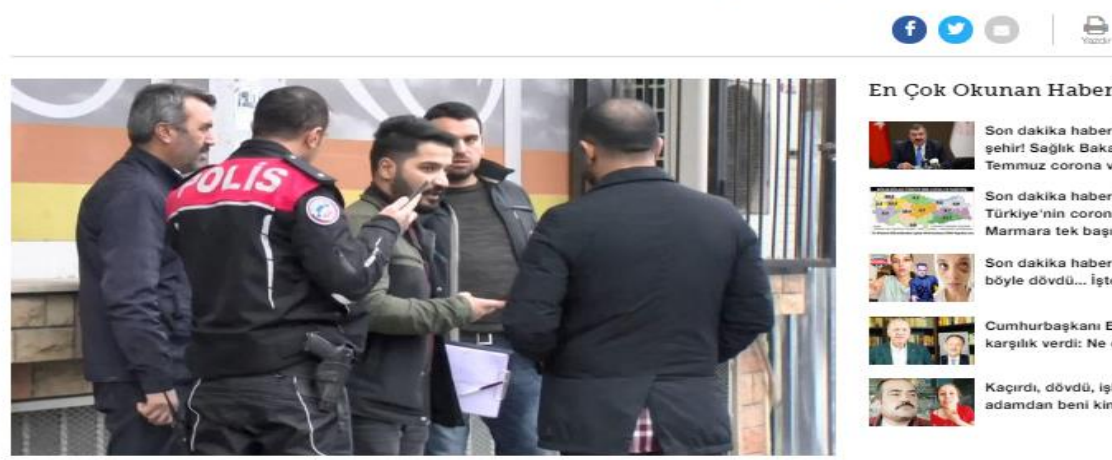

Abone of Gordenions

Tuzla'da bankadan çıkan bir kiși yanında bulunan 120 bin lirasını kendisini araçla takip eden kapkaççya kaptırdı. Polis olay yerinden kaçan șüpheliyi yakalamak için çalıșma bașlattı.

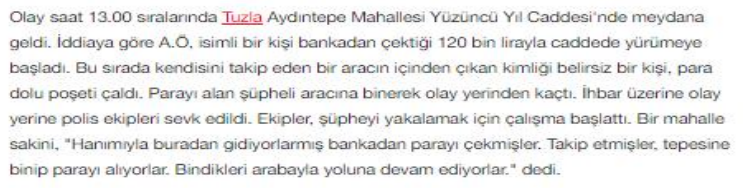

Picture 5: "snatching" on someone leaving the bank in Tuzla in the middle of the street news on hurriyet.com.tr (2020)

Source: screenshot, hurriyet.com.tr, 2020 
The news in Visual 5 (hurriyet.com.tr, 2020) is that a person leaving the bank in Tuzla is in a hatchery. Although it is stated in the title that the snatching took place in Tuzla, the word street was still used, and the immediate attention was drawn here. In the news content, "He started to walk on the street with 120 thousand Turkish liras". Meanwhile, an unidentified person, who came out of a vehicle following him, stole the bag full of money. However, the main emphasis in the statement is that it is dangerous to go out with that amount of money. In the photograph, a square is used to give the impression that the police have taken the incident under control. No expression alienates the street, like in the headline and news content. However, when the news is evaluated as a whole, the street is ultimately coded as a hostile place. The impression that the street is unsafe was first felt in the title and implicitly implied in the text.

\section{Damat dehşeti! Sokak ortasında kurşun yağdırdı}

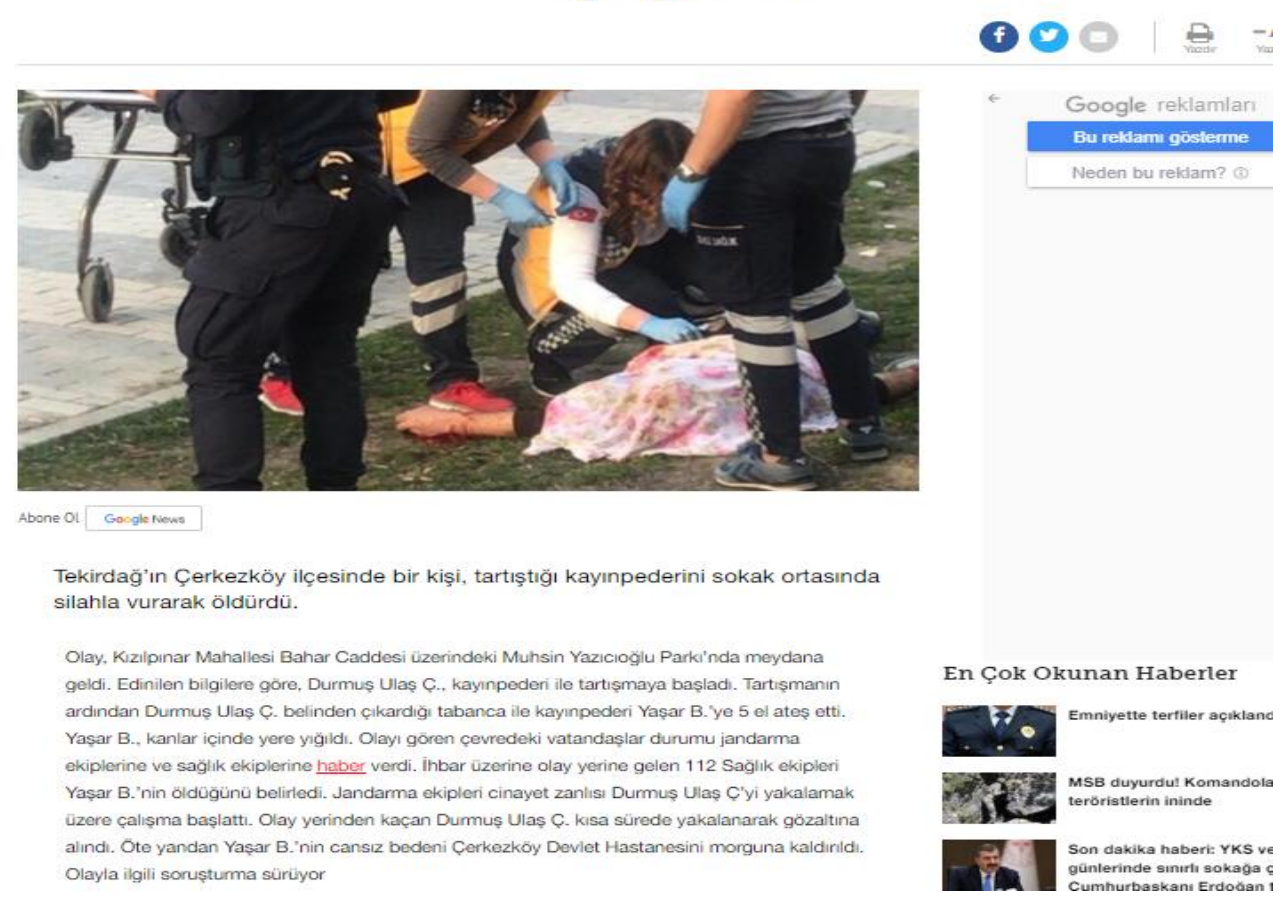

Picture 6: Groom horror: a bullet rained down in the middle of the street news on hurriyet.com.tr (2020)

Source: screenshot, hurriyet.com.tr, 2020 
The Street in the Focus of Concepts of Security/Insecurity: Representation of News About the Street on Internet News

"Groom Horror! An example of a news story called "he rained bullets in the middle of the street" (hurriyet.com.tr, 2020) is the Cerkezkoy District of Tekirdag, where a person killed his father-in-law. The word street is coded as a place to be afraid of the street, using phrases such as terror in the News title, lead rained down. Besides, the phrase bridegroom horror used in the title emphasized that a domestic issue was being moved to the street. The phrase "shot and killed in the middle of the street" in the news text refers to the street as a place of violence but describes the criminal device. These statements form an anti-street discourse, and the street is shown as a dangerous place, albeit indirectly. Thus, the perception is created that the street is the environment that triggers violence. A photo taken after the incident shows the lifeless body of the person who died and paramedics who came to intervene. The dead man's lifeless body lying in the street and his bloodied arm dramatized the incident.

Nevertheless, it feels like we can witness fights and murders, even if nothing happens to us on the street. Because, as Avci stated (2017: 15), the need for security includes protecting individuals from the violence heard/seen rather than being directly subjected to violence. It should be taken into account that the culture of fear that is essentially created can cause an attack on people at any moment. 

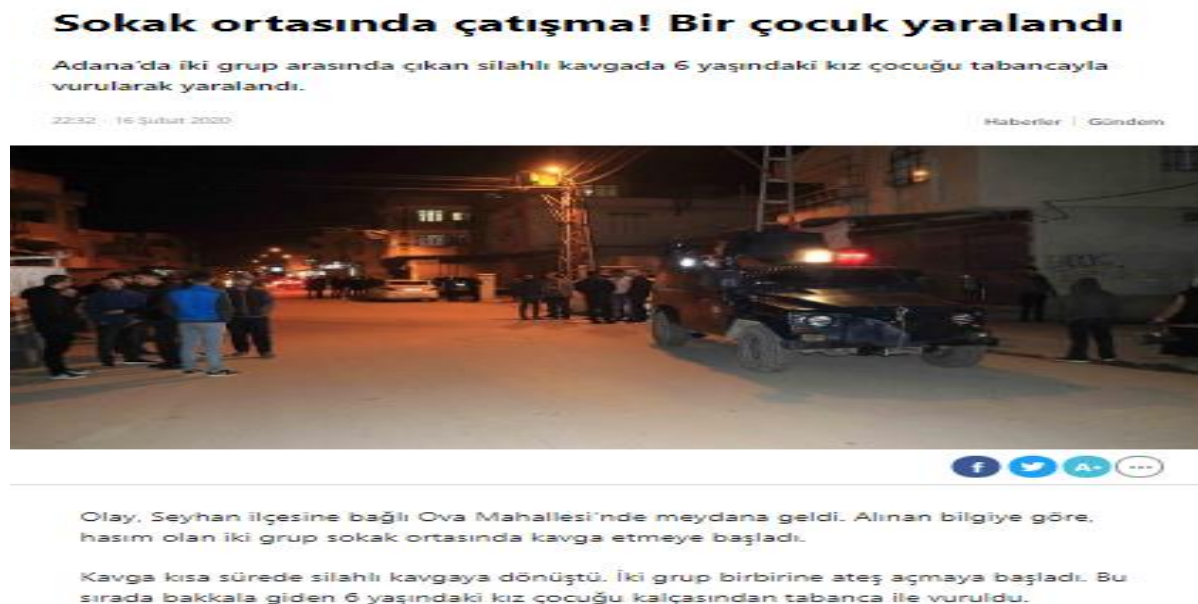
surada bakkala giden 6 yasundaki kiz coouğu kalcasundan tabanca ile vuruldu.

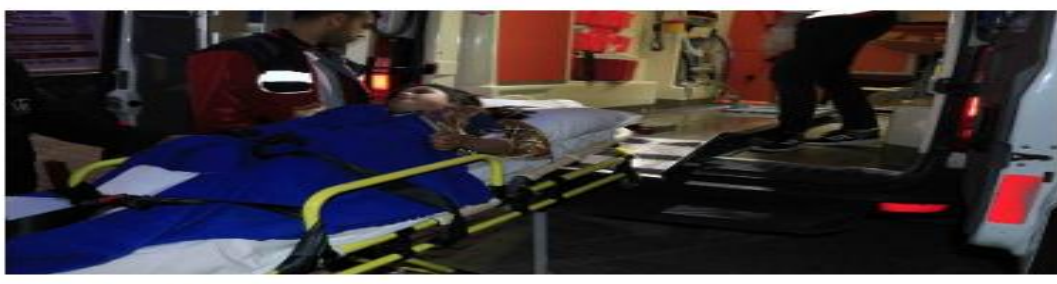

Kızlarının vurulduğu fark eden jile çocuklaruna hemen özel bïr hastaneve göturdu. Ozel hastanede tedavisi yapilan çocuk Adana Şehir Hastanesine sevk oldu.

olis olay yerinde bulunan bos kowanlarda

Picture 7: Clash in the middle of the street! A child injured on the news website sozcu.com.tr (2020)

Source: screenshot, sozcu.com.tr, 2020

The news (sozcu.com.tr, 2020) is about the injury of a 6-year-old boy who went to the grocery store to buy bread in a fight between two groups in Adana. The underlining that the child is shot in the street while going to the grocery store creates the perception that the street is not reliable even as a transition point from one place to another and gives the impression of how dangerous the streets are for children. Two different photographs were used in the article. The first is the place where the event took place. In the photo, 4-5 groups of people gathered in different street parts, and a military vehicle is seen. Although the street is crowded, silence prevails, and people feel uneasy. The fact that the military vehicle is still there increases the thought that the danger continues. In the other photo, an image of the injured child is taken on a stretcher while being put into the ambulance. The photograph of 
The Street in the Focus of Concepts of Security/Insecurity: Representation of News About the Street on Internet News

the child, whose eyes are closed, giving the impression of fainting, increases the dramatics; on the other hand, it reinforces the street's insecurity.

\section{Sokak ortasında liseli kıza dehşeti yaşattı!}
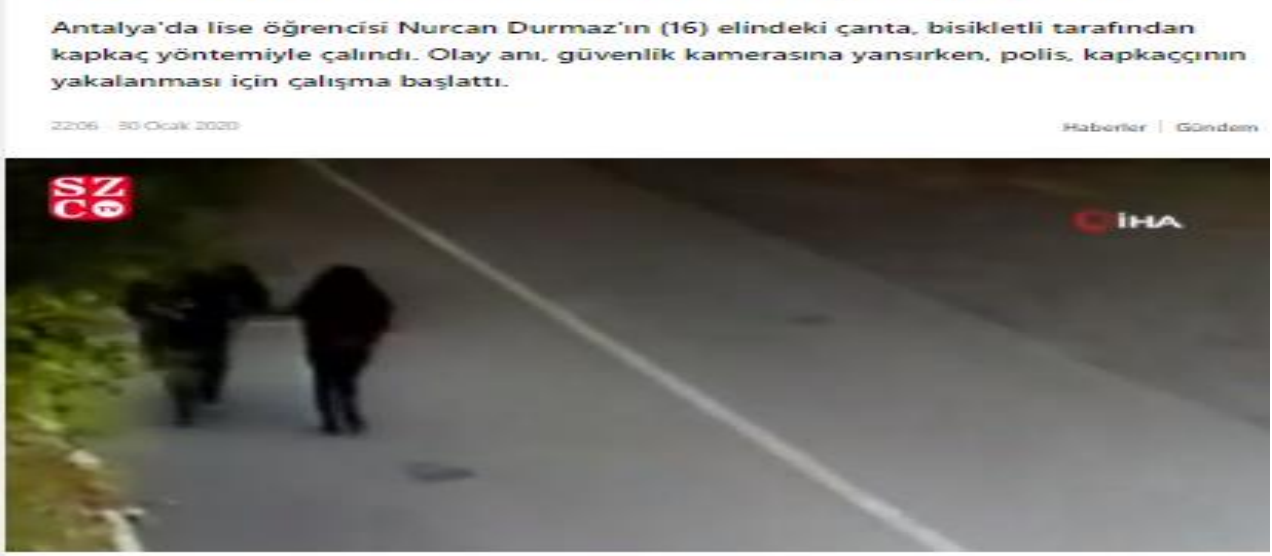

Olay, saat 13.30 siralarında. Muratpaşa ilçesine bağlu Kızıltoprak Mahallesi 917 Sokakta meydana geldi. Mahalledeki evinden ģikan lise ögrencisi Nurcan Durmaz'in arkasından yaklagan, siyah montlu bisikletli, elindeki çantayı kapkaçyöntemiyle çald.

Sok yaşayan Durmaz. kapkaç̧yy bir süre takip ettikten sonra 112 Acil Çağrı Merkezi'ne haber verdi. ihbarın ardından bölgeye çok sayıda polis ekibi sevk edildi. polis. Durmaz'in verdiği bilgiler doğrultusunda bolgede çalıgma basllatta.

Nurcan Durmaz, olayın nasıl gerçeklegttiğini polis ekiplerine anlatta. Durmaz'in çantasında arızalı telefon, oğrenci kimlik kartı ile 50 lira olduğu oğrenildi. Polis. kapkaç̧y' yakalamak için çalıs̆malannı sürdürüyor.

Ote yandan kapkaç ani, yakındaki sitenin güvenlik kamerasınca kaydedildi. Gönuntülerde Nurcan Durmaz'ın kaldınmda yürüdügü, arkasından gelen bisikletlinin çantayı kapıp, kaçtığı anlar yer aldı. (DHA)

Picture 8: High school girl was terrified in the middle of the street on the news website sozcu.com.tr (2020)

Source: screenshot, sozcu.com.tr, 2020

The content of the news titled "High School Girl Lives Terror in the Middle of the Street" (sozcu.com.tr, 2020) is a girl who is a high school student. The title has been constructed in a way that causes fear and anxiety to the reader. What is the horror in the title can be understood only after reading the spot? While a high school girl student was presented with a horror expression, it was underlined how dangerous it was to walk alone on the street. 
Video recorded by security cameras was used in the news, and the moments when the girl was snatched were shared with the reader. The absence of anyone on the street while the high school girl is snatched in the images may negatively affect the reader's subconscious. Thus, the reader will feel that when she/he is alone in the street or when someone approaches him, he will be snatched at any moment.

\section{Sokak ortasinda uyuşturucu satışı}

istanbul Arnawutkōy'de sokaktan geçen insanlara aldurış etmeden uyuşturucu satışı yaptığ iddía edilen bir kiși, polis tarafundan yakalandı. Gözaltına alınan süpheli tutuklanarak cezaevine gönderilirken. süphelinin uyuşturucu madde satıs̆ı yaptığı anlar ise bir is yerinin güvenlik kameralar tarafundan saniye saniye kaydedildi.

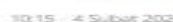

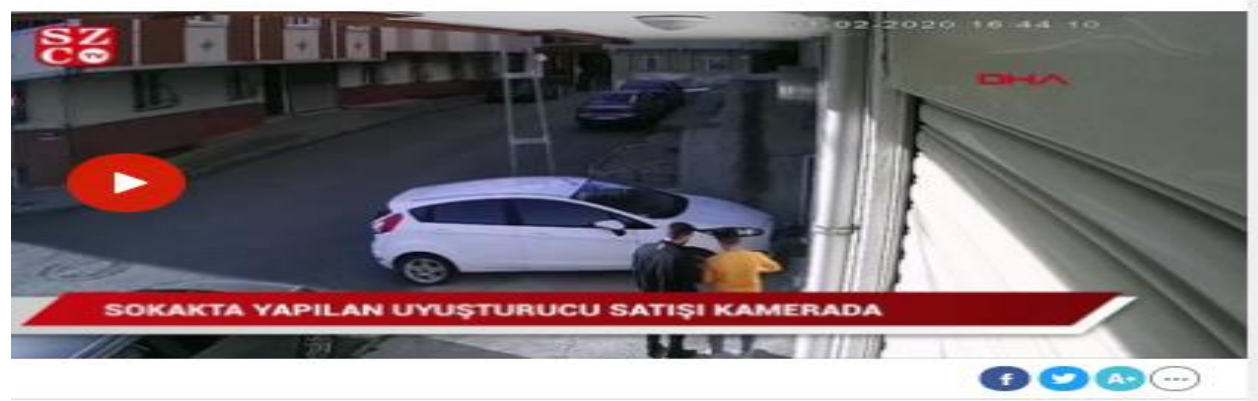

Arnavutkäy Merkez Mahallesilnde sokaktan gecen insanlara aldirs etmeden upusturucu madde sattığ iddia edilen $I_{\text {. }}$.. mahalle sakinlerinin dikkatini çekti. Mahalle sakinlerinin ihbarını değerlendiren Arnavutköy Emniyet Müdürluğüne bağb Mobil Park Ekipleri harekete geçti.

UYUSTURUCU TICARETI GÜVENLIK KAMERALARINA YANSIDI

i.Myi kısa surede yakalayarak gözaltun a alan ekipler yaptikiarı ust aramasinda satısa hazar 16 gram uyusturucu madde ve satıştan elde ettiği dusunulen bir miktar para

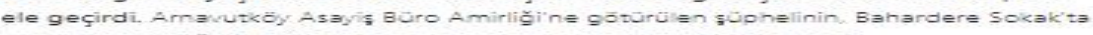
uyusturucu sattığ bilgisi uzerine güenlik kamera görüntuleri incelend

İ́min yanına gelen 2 kişiye uyuģturucu madde verdiği ve karşılığında da para aldığ görüntülere yansıdığ belirlendi. Emniyetteki işlemlerinin ardindan adliyeye sevk edilen i.Y." "uyugturucu madde ticareti yapmak" suçundan tutuklanarak Metris cezaevine gönderildi.

Picture 9: News on sozcu.com.tr titled Drug Sale in the middle of the street (2020)

Source: screenshot, sozcu.com.tr, 2020

In the news in Visual 9 (sozcu.com.tr, 2020) the street is positioned as a place where drugs are sold. The statement that "drugs are sold without paying attention to people passing through the streets ..." in the news content emphasizes the street's distrust. These statements create the perception that "the streets are so unsafe now that even drug sales can be made publicly". The news featured images of drug sales reflected on security cameras. Thus, the 
The Street in the Focus of Concepts of Security/Insecurity: Representation of News About the Street on Internet News

insecurity of the street has been proven by video. When the news is first clicked, an image appears in front of the reader in which the street is given from a wide-angle. In the photo, there are two people and two cars turned. Here, a deserted street draws attention rather than the images of drug traffickers. Therefore, the images show that the streets are dangerous rather than the danger of drug sales, and the real issue is shown like this.

\section{Conclusion}

The media, which tells us what is happening around us and, in the world, also tells us how to interpret what we hear. The media forms an opinion about a particular subject, event, or person with the news and programs it publishes. On the one hand, the media, which meets the needs of individuals to receive news, on the other hand, determines the framework in which the subject will be discussed with the language and words used in the news. Media tools do this by subconsciously processing it, thus creating a perception of the environment and the world we live in. The texts produced in online news sites, which are the source of this research, are also not real but represent the truth.

According to Alexa (alexa.com, 2020) data, in the study, we selected and analyzed nine news from the three most clicked news websites; it was seen that internet news sites constructed the street as a dangerous place through texts and photos. The street is generally shown in this news as a place where private life problems are reflected, criminal cases are experienced, and ultimately as an unsafe place. Three different news sites were discussed in the study; however, it drew attention that the language used, and the reference frames were similar. It has been observed that sometimes the same news was published on all three news sites with the same title, image, and content.

The perception is created that threats and risks can be faced on the street at any time. In the news in question, phrases such as 'on the street' and 'in the middle of the street' are often preferred. On the other hand, the street is used in the news and words such as horror, brutality, and snatch. Thus, the street is encoded in the reader's subconscious as a terrible, uncanny public space. Especially in the news, where personal issues are moved to the street, the street is fictionalized as an encouraging crime environment. Another aspect that has attracted attention in the news is the installation of the idea that the streets are more dangerous for women. While the news emphasizes that a street is unsafe, it says that individuals should stay away from this unsafe place. However, it is necessary to consider that individuals may become increasingly obsessed with risk in society (2001: 38), which can cause fear, panic, tension, and phobias in society, whether it is a constant desire to live in a safe environment or, as Furedi calls it, the blessing of security.

The truth is that media texts, coupled with prejudice patterns that exist in society, have a force that reinforces negativity. It has been negated in the street news, sometimes directly and sometimes indirectly. This situation proves that media workers have adopted the negative news language for the street. In summary, internet news sites encode the street with phrases 
that imply a dangerous and uncanny place. This situation creates a reality in the reader's mind and spreads over time to all society members. Thus, the street turns into a place to escape; also, the belief that we live in an increasingly insecure world is growing. Media members have a significant role in destroying this meaning attributed to the street. In line with the results of the analyzed news, the following suggestions can be submitted to internet news sites:

In line with the results of the analyzed news, the following suggestions can be submitted to internet news sites:

- $\quad$ The place where the event takes place should not be set up on the street. Where the incident takes place, address information of that place should be given.

- Street; Care should be taken not to be used side by side with negative words such as horror, brutality, beat, stabbed, killed.

- $\quad$ Posting photos that create fear, panic, and street phobia for the reader should be avoided.

- Molded expressions such as "in the middle of the street", "in the street", "horror in the street" should not be used in the news.

- The language of news that creates the perception that the incident is separated from its main context and that the street is inciting crime should be avoided.

\section{References}

Aktaş, G. (2017). The practices of urban space from the viewpoint of women, 27, 136-149.

Alexa Internet Inc. (2020, Mar 30) Alexa top sites in Turkey. Retrieved from http://www.alexa.com/topsites/countries/TR.

Avc1, M. G. (2017). Marketing security: crime and violence as a marketing tool, [ICOMEP 2017 SPECIAL EDITION]: 9-16.

Bauman, Z. (2000). In search of politics. Metis Publications.

Bayraktar, N., Akyol, E. \& Yücel, Ç. (1994). A venue: Atatürk Kindergarten-Umay pavyonu. Mimarlı Dergisi, 260, 43-46.

Browning, R., Jackson, Al. (2013). The social ecology of public space: active streets and violent crime. Urban Neighborhoods Christopher, 51(4): 1009-1043.

Cangöz, İ. (2018). Kadınsız kentler/cities without women. Varlık Journal, 1327(4): 29-31.

Çaki, F. (2017). Streets as belonging and space: a typology proposal within the Balıkesir case study framework. Çekmece İzü Social Sciences Journal, 5(10-11): 25-54.

Çelik, H.\& Ekşi, H. (2008). Discourse analysis. Marmara University Atatürk Faculty of Education Journal of Educational Sciences, 27(99): 99-117. 
The Street in the Focus of Concepts of Security/Insecurity: Representation of News

About the Street on Internet News

Doyuran, L. (2018). Critical discourse analysis as a mediatic working area (for example, in television series) Erciyes Communication Journal, 5(4): 301-323.

ensonhaber.com.tr. (2020 Jan 13) He beat a woman with a stick in the middle of the Street in Gaziosmanpaşa on the news [Press release]. Retrieved from https://www.ensonhaber.com/ic-haber/gaziosmanpasada-sokak-ortasinda-kadinisopayla-dovdu.

ensonhaber.com.tr. (2020 Jan 30) A person set his house on fire in Adana on the news [Press release]. Retrieved from https://www.ensonhaber.com/3-sayfa/adanada-bir-kisi-eviniatese-verdi.

ensonhaber.com.tr. (2020, Feb 11) He was stabbed to death in the street on his way to work [Press release]. Retrieved from https://www.ensonhaber.com/ic-haber/ise-giderkensokakta-bicaklanarak-olduruldu.

Furedi, F. (2001). Culture of fear: risk-taking and the morality of low expectation. Ayrintı Publications.

Gökgür, P. (2008). The location of public sphere in urban spaces. Bağlam.

Gür, T. (2013). Discourse analysis as a postmodern research method, Zeltschrlft für die Welt der Türken/Journal of World of Turks, 5(1): 192.

hurriyet.com.tr. (2020, Jan 28) "snatching" on someone leaving the bank in Tuzla in the middle of the street [Press release]. Retrieved from https://www.hurriyet.com.tr/gundem/tuzlada-bankadan-cikan-kisiye-sokak-ortasindakapkac-41431204.

hurriyet.com.tr. (2020, Feb 5) Recorded in İzmir! Fire the gun in the middle of the street [Press release]. Retrieved from https://www.hurriyet.com.tr/gundem/izmirde-kaydedildisokak-ortasinda-ates-acti-41439514.

hurriyet.com.tr. (2020, Mar, 7) Groom horror: a bullet rained down in the middle of the street [Press release]. Retrieved from https://www.hurriyet.com.tr/gundem/damat-dehsetisokak-ortasinda-kursun-yagdirdi-41463626

Karaman, A. (1991). The problem of meaning and scale in the design of public spaces with examples. Public spaces design and urban furniture symposium 15-16 May 1989. Istanbul University Press.

Kula S. \& Çakar B. (2015). The relationship between perceived life satisfaction and safety of people in society within the frame of Maslow's hierarchical needs Maslow, Bartın University I.I.B.F. Journal, 6(12): 191-210.

Lefebvre, H. (2013). The urban revolution. Sel Publications. 
Ömeroğlu, Ö. (2012). Fear of crime, deterrent of punishment and small crimes. Gazi University Law Faculty Journal, 16(4): 329-370.

Özer, Ö. (2015). "Critical discourse analysis in the case of Teun Adrian van Dijk”. In Besim Yıldırım (Eds.),With Application of Methods and Examples in Communication Research (pp.197- 287), Literatürk Academia.

Sennett, R. (1999). The conscience of the eye: the design and social life of cities. Ayrnnt1 Publications.

Sennett, R. (2002). The fall of public man. Ayrıntı Publications.

sozcu.com.tr. (2020, Jan 30). High school girl was terrified in the middle of the street [Press release]. Retrieved from https://www.sozcu.com.tr/2020/gundem/sokak-ortasinda-liselikiza-dehseti-yasatti-5598207/.

sozcu.com.tr. (2020, Feb 4). Drug sale in the middle of the street [Press release]. Retrieved from https://www.sozcu.com.tr/2020/gundem/sokak-ortasinda-uyusturucu-satisi$5605477 /$.

sozcu.com.tr. (2020, Feb 2). Clash in the middle of the street! A child injured [Press release]. Retrieved from https://www.sozcu.com.tr/2020/gundem/sokak-ortasinda-catisma-bircocuk-yaralandi-5628813/.

Taylan, H.H. (2011). The comparison of content analysis and discourse analysis which are used in social sciences. Bingöl University Social Sciences Journal, 1(2): 63- 76.

Tutal, N., Ülgen, E. (2018). Siya Siya Direniş/Political Resistance. Varlık Journal, 1327(4): 6-12.

TDK (2011). Turkish Dictionary. Turkish Language Society.

The young Foundation (2008). Understanding Neighbourliness And Belonging. [online]. [06.01.2021]. Available at: https://youngfoundation.org/wpcontent/uploads/2013/02/Understanding-neighbourliness-and-belonging-September2008.pdf. 